$$
\text { DOE/WIPP- } 95-2120
$$

\title{
THE WIPP RCRA PART B PERMIT APPLICATION FOR TRU MIXED WASTE DISPOSAL
}

\author{
Jack E. Johnson \\ Westinghouse Waste Isolation Division \\ Craig A. Snider \\ Department of Energy, Carlsbad Area Office
}

\begin{abstract}
In August 1993, the New Mexico Environment Department (NMED) issued a draft permit for the Waste Isolation Pilot Plant (WIPP) to begin experiments with transuranic (TRU) mixed waste. Subsequently, the Department of Energy (DOE) decided to cancel the on-site test program, opting instead for laboratory testing. The Secretary of the NMED withdrew the draft permit in 1994, ordering the State's Hazardous and Radioactive Waste Bureau to work with the DOE on submittal of a revised permit application. Revision 5 of the WIPP's Resource Conservation and Recovery Act (RCRA) Part B Permit Application was submitted to the NMED in May 1995, focusing on disposal of $175,600 \mathrm{~m}^{3}$ of TRU mixed waste over a 25 year span plus ten years for closure.
\end{abstract}

A key portion of the application, the Waste Analysis Plan, shifted from requirements to characterize a relatively small volume of TRU mixed waste for on-site experiments, to describing a complete program that would apply to all DOE TRU waste generating facilities and meet the appropriate RCRA regulations (Title 40, Code of Federal Regulations, Parts 260270). Waste characterization will be conducted on a waste stream basis, fitting into three broad categories: 1) homogeneous solids, 2) soil/gravel, and 3) debris wastes. Techniques used include radiography, visually examining waste from opened containers, radioassay, headspace gas sampling, physical sampling and analysis of homogeneous wastes, and review of documented acceptable knowledge. Acceptable knowledge of the original organics and metals used, and the operations that generated these waste streams is sufficient in most cases to determine if the waste has toxicity characteristics, hazardous constituents, polychlorinated biphenyls (PCBs), or RCRA regulated metals.

The repository is composed of eight panels and two panel equivalents (access drifts), with each being designated as an independent Hazardous Waste Management Unit (HWMU). Revision 5 of the Permit Application introduces partial closure of each underground HWMU when filled, and final closure of the entire repository following decontamination of the Waste Handling Building (WHB). Panel closure is accomplished by a multipart engineered panel closure system to be installed in the entries of each HWMU, keeping the emitted Volatile Organic Compound (VOC) concentrations well below environmental performance standards.

The NMED may issue a Notice of Deficiency (NOD) upon completion of the technical review and interactive discussions held with the DOE. The NMED will publish a draft permit and schedule a comment period and public hearings, following the DOE's response to the NOD.

Processing and final preparation of this report was performed by the Waste Isolation Pilot Plant Management and Operating Contractor for the U.S. Department of Energy under Contract No. DE-AC04-86AL31950 


\section{BACKGROUND}

The WIPP site has been set aside from public use to host a deep geologic repository for TRU mixed waste. The WIPP has both surface and underground facilities constructed and ready to begin disposal operations. The underground repository has been particlly mined $650 \mathrm{~m}$ beneath the surface within a thick bedded salt formation. The repository is eligible for permitting as a miscellaneous unit under state and federal regulations (RCRA). A permit is required under the New Mexico Hazardous Waste Act and its implementing regulations for hazardous waste management operations.

In September 1994, the NMED withdrew the draft hazardous waste permit at the WIPP facility (issued in August 1993) after the DOE elected to cancel the in situ tests that were covered by that draft permit, requesting the DOE to submit a revised permit application.

The revised Part B Permit Application is organized in accordance with the RCRA application checklist (1). The NMED issued numerous comments as their technical review proceeded. Most of the comments were requests for more detailed information. The DOE responded to each comment and drafted new text and supporting information where appropriate. These revisions were discussed during meetings with the NMED prior to their issuing the NOD letter.

TRU mixed waste to be received at the WIPP exists in a variety of physical forms, ranging from unprocessed laboratory trash (e.g., tools, paper, glassware, gloves) to solidified wastewater treatment sludges resulting from plutonium reprocessing and fabrication as well as from research and development activities at various DOE defense program facilities. Most TRU mixed waste is contact-handled $(\mathrm{CH})$ but some with a higher intensity of radioactivity is remote-handled $(\mathrm{RH})$. In the future, significant quantities of TRU mixed waste may be generated from environmental restoration, decontamination, or decommissioning activities. TRU mixed waste containers are required to be vented through high-efficiency particulate air (HEPA)-grade filters to preclude pressurization caused by potential gas generation.

\section{PERMIT APPLICATION}

The permit application is organized into 13 chapters, with headings and subheadings in accordance with the RCRA application checklist (1).

Chapter A, "RCRA Part A Application Certification"

Chapter A consists of Part A of the application. The Part A contains the facility's owner and operator information, type of facility, capacity, process information, estimated annual waste receipts, and certification. The DOE is the WIPP facility owner/operator, and, in accordance with DOE policy, the Management and Operating Contractor, Westinghouse Waste Isolation Division, has signed the certification as co-operator.

\section{Chapter B, "Facility Description"}

The facility description includes some history of the site selection and the development leading up to construction. The basic requirements of the WIPP Land Withdrawal Act of 1992 are presented. Eight underground panels of seven rooms and two access drifts each comprise 
the repository and are to be permitted as HWMUs. The disposal area access drifts will probably also be used in the future as panels 9 and 10. As each panel is filled, it will be closed off to isolate that waste from the rest of the facility.

The WHB areas used for waste receipt, handling, inspection, etc., are included for permitting as container storage units (HWMUs), consisting of the $\mathrm{CH}$ Bay, the $\mathrm{RH}$ Bay and hot cell complex in the WHB, and the parking area south of the WHB. Waste is received in TRU Package Transporters (TRUPACT-II) and road or railroad casks (designed to meet Department of Transportation Type B requirements), which are unloaded inside the WHB. Both road and rail transportation accesses are available.

The $\mathrm{CH}$ waste containers will be inspected in the $\mathrm{CH}$ bay as they are removed from the TRUPACT-11, loaded onto a facility pallet, moved to the waste hoist conveyance, and lowered down the shaft to the repository horizon via the waste hoist conveyance, and transported to the HWMU where the waste is disposed. The road cask with RH waste is unloaded in the RH bay into the hot-cell complex remotely, where the waste container can be identified, checked for external contamination, and loaded into the facility cask for transport underground via the waste hoist conveyance. The facility cask is transported to the HWMU and set on the emplacement machine, which faces a drilled hole in the salt. Shield valves allow the waste container to be pushed into the hole without exposing the operators to radiation. A shield plug goes into the hole afterward to assure safe personnel access to the room for $\mathrm{CH}$ waste stacking activities after the emplacement machine has been removed.

Other information in Chapter B is provided on location, topography, distance from bodies of water, prohibition of hydrocarbon wells on the site, vicinity of water wells, lack of nearby population centers, cattle grazing leases, site access control, and compliance with other portions of the regulations, including the floodplain and seismic standards. The only pathway for hazardous emissions is by air, either from the underground or the WHB exhaust.

Chapter C, "Waste Analysis Plan"

Generators are required to characterize all wastes planned for disposal at WIPP, using formal programs adhering to the requirements of the Waste Analysis Plan (WAP), the WIPP Waste Acceptance Criteria (WAC), and the TRU Waste Characterization Quality Assurance Program Plan (QAPP). Both sampling and analysis programs and acceptable (process) knowledge will be used in classifying the wastes. Some wastes have been in retrievable storage since 1970 and others will be generated in the future.

The previous permit application for test waste required characterizing 100 percent of the waste, although waste quantities were small and only two DOE generators were involved. The revision for disposal applies to all DOE TRU waste generator sites, possessing the full spectrum of waste streams. Waste characterization requirements for disposal have been developed to balance the quantity of data required to satisfy the regulator, yet prevent extensive increases in generator personnel exposure and excessive expense. Thus, the WAP establishes new WIPP TRU waste characterization requirements for all DOE generator sites planning to dispose of their TRU waste.

Waste characterization will be done on a waste stream basis. The waste streams fit into three broad categories: 1) homogeneous solids, 2) soil/gravel, and 31 debris wastes. 
Techniques to be used include radiography, visual examination of opened containers, headspace gas sampling, physical sampling and analysis of a statistically determined amount of homogeneous wastes, and review of documented acceptable knowledge.

Radiography is used to noninvasively examine waste containers (required for all stored waste and judiciously applied to newly generated waste) for physical form of the waste and to detect free liquids and other prohibited items.

Visual examination, an invasive technique, will be conducted on a statistical sample of waste containers from each waste stream and used to inspect waste contents and verify radiography results.

Headspace gas sampling and analysis are used to determine the concentrations of VoCs, hydrogen, and methane within the headspace of waste containers.

A statistically selected portion of homogeneous solids and soil/gravel wastes will be sampled for hazardous waste constituents and toxicity characteristic. Samples will be analyzed for VOCs, semi-VOCs, and metals.

Acceptable knowledge is used to classify debris waste. Knowledge of the original organics and metals used and the operations that generated these waste streams is sufficient to determine if the waste has a toxicity characteristic, hazardous constituents, PCBs, or RCRAregulated metals. RCRA-regulated metals present in debris waste are associated with specific waste materials (e.g., lead in leaded rubber gloves). Radiography, visual examination, and headspace gas sampling are used to collect data to provide confidence in acceptable knowledge.

Generator waste characterization also includes quality assurance (QA) requirements, applied through meeting the QAPP requirements by implementing site-specific QA Project Plans (QAPjP), which are submitted to the WIPP.for review and approval. The WIPP personnel will perform audits of the generator site waste characterization programs to verify that implementation of the QAPjPs is consistent with the requirements of the QAPP and the WAP.

There are three phases to waste shipment screening and verification. The first step involves submittal of a Waste Stream Profile Form to the WIPP for review. The next phase occurs prior to shipment wherein the electronically transmitted data package is reviewed and accepted by WIPP personnel after extensive edit and range checks conducted by the WIPP Waste Information System (database). This acceptance is based on successful completion of the WIPP audits of the generator's QAPjP activities, and a determination that the data meet the acceptance criteria. The third phase occurs after the shipment has arrived, but before it is accepted. This includes 1) a determination of the completeness and accuracy of the EPA Hazardous Waste Manifest, 2) a determination of waste shipment completeness, 3) a determination of land disposal restriction notice completeness, and 4) an identification and resolution of any waste shipment irregularities. 
Chapter D, "Facility and Process Information"

Facility and Process Information includes the TRU waste management facilities, equipment, and operations described in Chapter $B$, and compliance with the environmental performance standards for the WIPP.

The physical attributes of the WIPP site contribute to the ability of the facility to isolate TRU mixed waste and ensure that human health and the environment are protected. The average annual precipitation is only $30 \mathrm{~cm}, 96$ percent of which is returned to the air through evapotranspiration. The geologic sequence at this site mainly consists of three evaporitebearing formations, the Castile (deepest), Salado, and Rustler. The repository is located in the Salado formation, an approximately $610 \mathrm{~m}$ thick bedded halite, with some carbonates, anhydrites, and clay seams. It is regionally extensive, has extremely low permeability, behaves in a plastic manner under pressure, contains only fluids that are saturated with salt, and lies between the other two formations which contain highly impermeable layers that offer further confinement for the waste.

Four shafts connect the underground area with the surface. The Waste Shaft is located within the WHB. The Air Intake Shaft and the Salt Handling Shaft provide ventilation underground. The Exhaust Shaft serves as a common exhaust air duct for all underground areas.

The WHB was designed to withstand a design basis tornado with a maximum windspeed of $294 \mathrm{~km} / \mathrm{hr}$ and a design basis earthquake acceleration of $0.1 \mathrm{~g}$.

Release of hazardous waste or hazardous constituents to the air that may have adverse effects on human health or the environment is unlikely. VOCs constitute the greatest hazard, but the maximum concentration of any VOC release has been calculated to be at least two orders of magnitude below the environmental performance standards.

Chapter E, "Groundwater Monitoring"

In the past, groundwater monitoring at the WIPP has focused on the Culebra member of the Rustler Formation above the repository, as it represents the most permeable and most likely hydrologic contaminant migration pathway. No credible pathway has been established for contaminant transport to aquifers below the repository horizon, as there is no hydrologic communication between the two. It is the DOE's position that the migration of hazardous waste or hazardous constituents from the WIPP repository to the environment through groundwater is unlikely. The bedded-salt formation acts as an extremely low-permeability regional barrier isolating the repository from water-bearing units. Also the plasticity and geologic behavior of halite will tend to close any potential pathways created by excavation.

For hazardous waste or hazardous constituents to migrate from the repository to groundwaterbearing units, there must first be a pathway, such as a shaft. All four shafts extending to the repository horizon have been constructed to minimize the infiltration of water from the overlying water-bearing units into the repository during its operational life. After waste emplacement, the shafts will be filled with permanent low-permeability seals and plugs designed to inhibit migration of fluids to and from the repository. 
Surface water is generally absent in the immediate vicinity of the WIPP facility.

Chapter F, "Procedures to Prevent Hazards"

Security, facility inspections, structures, equipment, procedures, and other measures taken to prevent hazards during the disposal operations are described.

Security requirements are met by 24 -hour surveillance and a barrier to control entry to the facility at all times.

Equipment instrumental in preventing, detecting, or responding to environmental or human health hazards is inspected periodically for malfunctions, deterioration, potential for operator errors, and discharges which could lead to a release of hazardous waste constituents to the environment, or pose a threat to human health.

The WIPP facility has a variety of communications systems and emergency response equipment and possesses a continuous water supply to meet emergency situations. The intraplant communication systems include two-way communication by the public address (PA) system and its intercom phones and paging channels, an intraplant telephone system, mine phones, pagers and plectrons, portable two-way radios, and local and facility-wide alarms. External communications are provided by the commercial telephone system and two-way radios for summoning emergency assistance from off site or communicating with outside agencies.

The water supply system is for domestic use and fire control for the maximum credible fire. The underground has no water supply, but has fire extinguishers of various types and a rescue truck with chemical and foam extinguishers.

Diesel generators provide power in the event of utility power loss and the uninterruptible power supply is always available to supply important monitoring systems. Thus, during a power outage, the ventilation systems are powered by the diesel generators and all waste handling operations are shut down into a mode providing personnel and facility safety.

Chapter G, "RCRA Contingency Plan"

The Contingency Plan defines responsibilities, provides guidance for coordination of activities, and minimizes hazards to human health and the environment from fires, explosions, or any sudden or nonsudden release of hazardous waste or hazardous waste constituents to air, soil, or surface water. In case of an emergency where a release results that may threaten human health or the environment, the RCRA Emergency Coordinator will activate the Contingency Plan. The provisions of the Contingency Plan apply to all HWMUs, the Waste Shaft, and supporting TRU mixed waste handling areas. Nonradioactive hazardous substances, hazardous materials, and hazardous wastes will also be managed in accordance with the Contingency Plan.

A RCRA Emergency Coordinator will be on site at the WIPP 24 hours a day, seven days a week, with the responsibility for coordinating emergency response measures. Persons qualified to act as the RCRA Emergency Coordinator are thoroughly familiar with the 
Contingency Plan, the TRU mixed waste and hazardous waste operations and activities at the facility, the locations of TRU mixed waste and hazardous waste activities, the locations on site where hazardous materials are stored and used, and the locations of waste staging and accumulation areas. Other personnel identified are 1) the Central Monitoring Room Operator, 2) the Emergency Response Team, 3) the Emergency Services Technicians, 4) the First Line Initial Response Team, 5) the Mine Rescue Team, 6) the Office Wardens, 7) the Chief and Assistant Chief Office Wardens, and 8) the Security Fire Support. The Contingency Plan will be activated only when the RCRA Emergency Coordinator determines that the activation criteria are met.

If notification of local authorities and or regulatory agencies is determined to be necessary, the RCRA Emergency Coordinator will assure that those notifications are made. The DOE policy is to provide accurate and timely information to the public by the most expeditious means possible concerning emergency situations at the WIPP site that may affect off-site personnel, public health and safety, and/or the environment.

Supplementing the on-site capabilities for emergency response, the DOE has Memoranda of Understanding with off-site emergency response agencies for fire response, medical assistance, and law enforcement. Since the WIPP facility is owned and operated by the DOE, other off-site DOE emergency response organizations could be called in for support.

Any incident requiring activation of the Contingency Plan will be reported to the operating record in detail. Notifications required by regulations will be made to the required regulatory agencies within the allotted time span.

Chapter H, "Personnel Training"

The WIPP's personnel training program meets the requirements of the RCRA. Preparing personnel to operate the WIPP facility in a safe and environmentally sound manner is the primary objective of the training program. All on-site personnel are provided with an introduction to RCRA and emergency preparedness within 30 days of employment. Other relevant training is provided to employees and their supervisors whose jobs are such that their actions or failure to act could result in a spill or release or the immediate threat of a spill or release of hazardous waste.

Required RCRA-related training is conducted by certified instructors and consists of classroom instruction and on-the-job training as appropriate. Certain positions require formal certification and are identified by Department Managers based on safety, complexity, and involvement with hazardous waste handling operations.

Hazardous waste management courses are offered at a frequency that ensures that new hires or transfers can receive relevant training within six months of assuming their new position. Employees do not work unsupervised in hazardous waste management positions until they have completed the requisite training.

The training program for emergency response ensures that personnel are able to respond appropriately and effectively to emergency situations by providing thorough training, including 
fire response elements, 40-hour miner training, Mine Safety and Health Administration requirements for medical and mine rescue, and lifesaving elements.

\section{Chapter I, "Closure Plans, Post-Closure Plans and Financial Requirements"}

This chapter was extensively revised to contain descriptions of the activities necessary to close the WIPP facility at the end of it's life and provide surveillance after closure. The previous revision detailed "clean closure" based on the possibility of having to retrieve and return all of the test waste. The WIPP is a federal project, so financial assurances for closure are not required to be addressed. The underground HWMUs (panels) will be closed individually as they are filled, with barriers constructed to limit accessibility of the hazardous constituents to the environment during continuing operations. Partial closure of each HWMU will be considered complete when the panel closure system is emplaced and operational, and the NMED has approved the closure. Possible backfilling of access drifts, plugging and sealing of the shafts, and dismantling of surface facilities will constitute final closure.

For the purposes of establishing a schedule for closure, the operating life may last 25 years, followed by a closure period of ten years for decontamination (both radiological and chemical), decommissioning, and final closure. The WIPP surface and subsurface facilities are planned to be dismantled (except for the hot cell portion of the WHB, which will remain as a portion of the Permanent Marker System) and either salvaged or disposed of. Paving and caliche will be removed and the surface area recontoured and revegetated. During the closure period, the DOE will continue to demonstrate compliance with applicable permit requirements. Facility monitoring procedures in place during operations will remain in place through final closure.

Decisions about closure activities may be based in part on analyses of potentially contaminated surfaces and media. Reliability of analytical data will be accomplished by following a Quality Assurance/Quality Control $(\mathrm{QA} / \mathrm{OC})$ program that mandates precision and accuracy of laboratory analyses. The documented QA/OC program currently in place at the WIPP meets the DOE OA requirements.

Final closure of the WIPP facility will prevent the intrusion of fluids into the repository, prevent human intrusion after closure, and minimize future physical and environmental surveillance. Access to the site of the repository's surface footprint will be controlled by the federal government as long as practicable and at least for the 100-year period considered under 40 CFR Part 191. This active control will preclude inadvertent intrusion into the disposed waste by deep drilling or mining natural resources.

The post-closure care period begins after completion of final closure of the facility and continues as long as necessary to satisfy regulatory requirements and to protect human health and the environment. During the post-closure period, the WIPP site will be maintained in a manner that complies with the applicable environmental performance standards. No postclosure monitoring for detection of releases is proposed since the migration of contaminants is unlikely. However, because there are other regulations that apply to the WIPP long-term performance, several techniques need to be evaluated (e.g., geophysical techniques and subsidence monitoring). 


\section{Chapter J, "Corrective Action for Solid Waste Management Units"}

The solid waste management units (SWMU) within the $41: 4 \mathrm{~km}^{2}$ WIPP site boundary were identified by the EPA Region 6 as requiring further investigation. Corrective actions are required only for SWMUs from which releases of RCRA hazardous wastes or hazardous constituents have occurred.

The definition of a SWMU has not been finalized by the EPA yet. WIPP uses the definition presented in the proposed Subpart S of 40 CFR Part 264. This definition states that SWMUs are "any discernible unit at which solid wastes have been placed at any time irrespective of whether the unit was intended for the management of solid or hazardous waste. Such units also include any area at or around a facility at which solid wastes have been routinely and systematically released." 16 SWMUs requiring further investigation have been identified by the NMED, which conducted a RCRA Facility Assessment for the EPA. Seven others were created by the DOE since the filing of the Revision 3 of the Permit Application for the test program. Units that are similar in physical characteristics or waste type are grouped within an SWMU description for the particular type of discernible unit.

The DOE will institute corrective actions necessary to protect human health and the environment for any release of hazardous waste or hazardous constituents from SWMUs at the WIPP facility. Authority for regulating corrective actions recently passed to the NMED.

Chapter K, "Other Federal Laws"

Other federal laws, Executive Orders (EO), and regulations which deal with environmental protection, or were evaluated for applicability to the operation of the WIPP facility, are listed. These were all assessed because of the nature of the WIPP's proposed activities and the proposed land use.

\section{Chapter L, "No-Migration Variance Petition"}

The history of the DOE's submittals of a No-Migration Variance Petition (NMVP) is summarized, as is the subsequent addendum to the EPA to demonstrate that the site characteristics, operational practices, and waste characteristics were sufficient to prevent migration of hazardous constituents beyond the unit boundary during the period planned for the test program.

The EPA issued a Conditional No-Migration Determination for the Test Phase. Subsequently, however, the DOE abandoned plans for testing waste at the WIPP. The DOE submitted a new Draft NMVP for the waste disposal in May 1995. A final NMVP for both operations and postclosure will be submitted in June 1996.

Chapter M, "Certification"

This is a statement of the DOE being the owner and operator of the WIPP facility with the Westinghouse Waste Isolation Division as the co-operator. Managers of both organizations have signed this certification. 


\section{RECENT ACTIVITIES}

The NMED determined the permit application to be administratively complete and during their subsequent technical review, hosted interactive discussions with the DOE and contractors for both organizations. The major comments received from the NMED were for much more detail to be supplied.

The DOE set a goal of receiving the Permit in August 1996. The DOE attempted to resolve the NMED's comments with expanded descriptions of all aspects of the facility design and operation, even those associated with the radiological controls. The DOE also attempted to reduce the quantity of comments in the NMED's Notice of Deficiency (NOD) letter via the interactive comment resolution process. All activities under DOE control continue to be aimed at meeting the set goal.

The DOE submitted a final response to the NMED's comments in mid-January 1996, following the early January technical exchange meeting with the NMED. The NMED told the DOE that, based upon the contents of the final response, they would review the responses and revised text, and issue the NOD in mid-February, which they did. The DOE was given 30 days to respond to the NOD, after which the NMED would develop the draft permit.

Upon issuance of the draft permit, a public comment period will be established. Public hearings are anticipated at various cities in New Mexico, in which the DOE will participate. The NMED will consider the testimony from the hearings and all comments received, and craft a final permit (or a denial) with all conditions they believe are necessary to protect the public safety and the environment from harm by the waste disposal operations at the WIPP facility.

\section{CONCLUSION}

The WIPP disposal-phase operating permit application was submitted to the NMED by the DOE in May 1995, and is described in some detail. Following a period of technical review, the NMED issued a number of comments, to which the DOE responded with draft revisions to the permit application. After several technical exchange meetings, the NMED issued an NOD in February 1996. A new revision to the application will be completed, along with written responses to each deficiency, and submitted to the NMED within the prescribed response time.

The next step is for the NMED to draft the permit, supplying their conditions for facility operations, and hold public hearings. Upon consideration of the oral and written responses during and after the hearings, the NMED is expected to issue the permit.

\section{REFERENCE}

1. US Environmental Protection Agency (EPA), 1989, "RCRA Part B Application Completeness/Technical Evaluation Checklist," Revision 7, August, 1989.

DOEMIPP-95-2120 


\section{DISCLAIMER}

This report was prepared as an account of work sponsored by an agency of the United States Government. Neither the United States Government nor any agency thereof, nor any of their employees, makes any warranty, express or implied, or assumes any legal liability or responsibility for the accuracy, completeness, or usefulness of any information, apparatus, product, or process disclosed, or represents that its use would not infringe privately owned rights. Reference herein to any specific commercial product, process, or service by trade name, trademark, manufacturer, or otherwise does not necessarily constitute or imply its endorsement, recommendation, or favoring by the United States Government or any agency thereof. The views and opinions of authors expressed herein do not necessarily state or reflect those of the United States Government or any agency thereof. 
